\title{
Suppression of erythropoiesis by Plasmodium vivax infection
}

\author{
Tasanee Panichakul ${ }^{1 *}$, Witchuda Payuhakrit ${ }^{2}$, Chokdee Wongborisuth ${ }^{3}$, Suradej Hongeng ${ }^{4}$, \\ Rachanee Udomsangpetch ${ }^{2}$ \\ From Parasite to Prevention: Advances in the understanding of malaria \\ Edinburgh, UK. 20-22 October 2010
}

\section{Background}

Reports of severe anemia due to $P$. vivax infection increase [1]. P. vivax is considered to infect reticulocytes and parasitemia is generally low, this suggests that in addition to the simple destruction of infected red cells there is another mechanism to induce anemia in vivax. A report of vivax malaria in bone marrow from severely anemia patients exhibited dyserythropoiesis [2]. Our study demonstrated that $P$. vivax could infect erythroblasts and erythroblast loss was at least partially attributed to direct killing by parasite invasion [3]. However, the mechanism involving in induction of anemia in vivax malaria is still unclear. Here, hematopoietic stem cells (HSCs) $/ \mathrm{CD} 34^{+}$cells from normal human cord blood were subjected to study the suppression of erythropoiesis by $P$. vivax infection. Erythroid cells derived from HSCs were cultured in serum-free medium supplemented with growth factors and cytokines. Intact or lysed $P$. vivax-infected erythrocytes (PV-IE) isolated from patient blood were added to erythroid cultures. Results showed both intact and lysed PV-IE could inhibit erythroid expansion by up to 50-55 \% compared with controls containing red cells (RBCs) (see Figure 1).

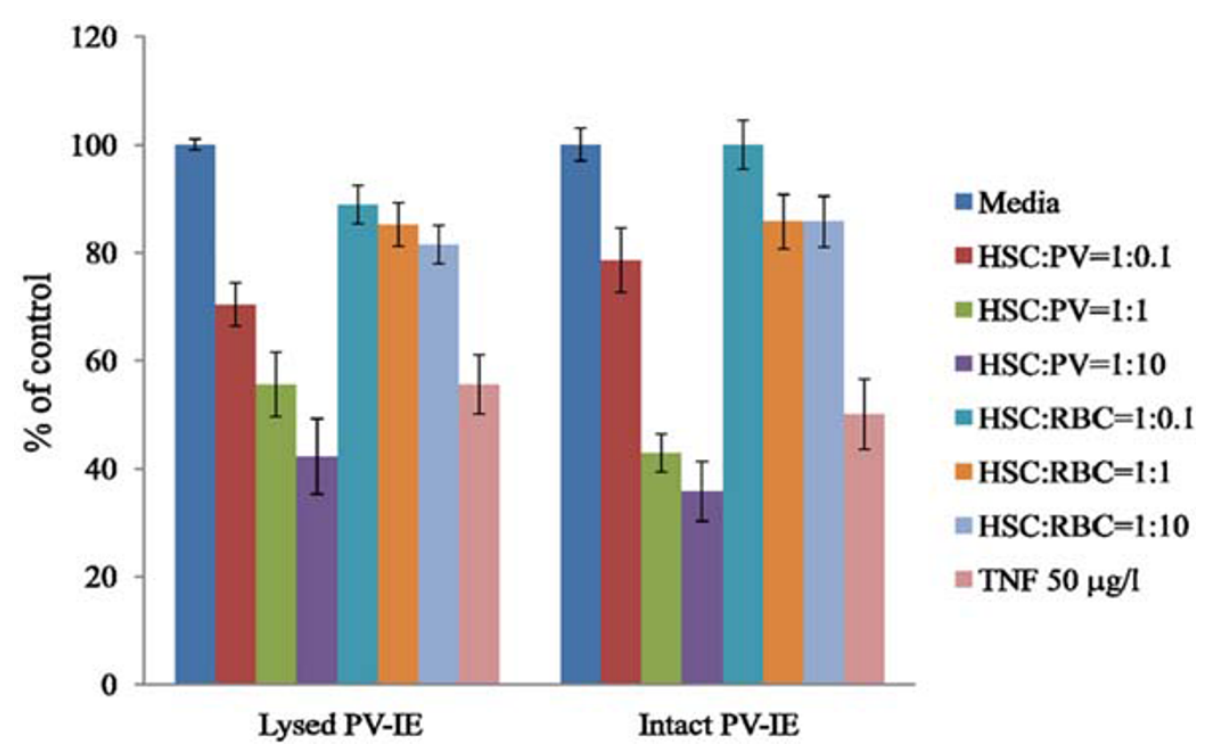

Figure 1 Inhibition of erythroid expansion. HSCS, 5 day-old, $10^{5}$ cells were cultured with intact or lysed PV-IE and further cultured up to 12 days. Intact and lysed RBCs and TNF- $\alpha$ were as controls.

${ }^{1}$ Faculty of Science and Technology, Suan Dusit Rajabhat University,

Bangkok, Thailand

Full list of author information is available at the end of the article 
The reduction of erythroid expansion was not significantly greater by intact PV-IE when compared with lysed PV-IE. The inhibition of cell expressing glyphorin A was up to $66.67 \%$ compared with controls.

\section{Conclusion}

$P$. vivax could inhibit erythroid growth and development and this suppression of erythropoiesis by $P$. vivax infection is plausible to involve in induction of anemia.

\section{Acknowledgements}

This was supported by Thailand research fund, Commission on Higher Education, Ministry of Education and Suan Dusit Rajabhat University, Bangkok, Thailand (MRG5380092).

\section{Author details}

${ }^{1}$ Faculty of Science and Technology, Suan Dusit Rajabhat University, Bangkok, Thailand. 'Department of Pathobiology, Faculty of Science, Mahidol University, Bangkok, Thailand. ${ }^{3}$ Research Center, Faculty of Medicine, Ramathibodi Hospital, Mahidol University, Bangkok, Thailand. ${ }^{4}$ Department of Pediatric, Faculty of Medicine, Ramathibodi Hospital, Mahidol University, Bangkok, Thailand.

Published: 20 October 2010

\section{References}

1. Kochar DK, Das A, Kochar SK, Saxena V, Sirohi P, Garg S, Kochar A, Khatri MP, Gupta V: Severe Plasmodium vivax malaria: a report on serial cases from Bikaner in northwestern India. Am J Trop Med Hyg 2009, 80:194-198.

2. Wickramasinghe $\mathrm{SN}$, Abdalla $\mathrm{SH}$ : Blood and bone marrow changes in malaria. Baillieres Best Pract Res Clin Haematol 2000, 13:277-299.

3. Panichakul T, Sattabongkot J, Chotivanich K, Sirichaisinthop J, Cui L, Udomsangpetch R: Production of erythropoietic cells in vitro for continuous culture of Plasmodium vivax. Inter J Parasitol 2007, 37:1551-1557.

doi:10.1186/1475-2875-9-S2-P35

Cite this article as: Panichakul et al:: Suppression of erythropoiesis by Plasmodium vivax infection. Malaria Journal 2010 9(Suppl 2):P35.

\section{Submit your next manuscript to BioMed Central} and take full advantage of:

- Convenient online submission

- Thorough peer review

- No space constraints or color figure charges

- Immediate publication on acceptance

- Inclusion in PubMed, CAS, Scopus and Google Scholar

- Research which is freely available for redistribution

Submit your manuscript at www.biomedcentral.com/submit 